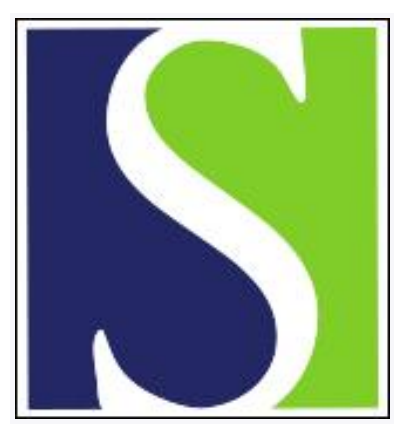

Scand J Work Environ Health 1978;4(4):336-338

https://doi.org/10.5271/sjweh.2700

Issue date: Dec 1978

\title{
Risk of infection from heavily contaminated air.
}

by Grunnet K, Hansen JC

Key terms: Salmonella; airborne bacteria; contaminated air; infection; infection risk; risk

This article in PubMed: www.ncbi.nlm.nih.gov/pubmed/104380

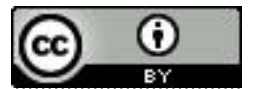




\title{
Risk of infection from heavily contaminated air
}

\author{
by KAI GRUNNET, M.D., D.P.H., and JENS CARL HANSEN, D.V.M.1
}

\begin{abstract}
GRUNNET, K. and HANSEN, J. C. Risk of infection from heavily contaminated air. Scand. j. work environ. \& health 4 (1978) 336-338. In a factory processing shea nuts the dust concentrations were found to be up to $145 \mathrm{mg} / \mathrm{m}^{3}[80 \%$ respirable $(1-5 \mu \mathrm{m})]$. Bacterial examination of the dust revealed that under the worst conditions observed a worker might inhale 350,000 bacteria per $8 \mathrm{~h}$. Of these, 3,000 were Ps. aeruginosa and 1,500 Salmonella spp. of nine different types. The possible health effects of these findings are discussed.
\end{abstract}

Key words: airborne bacteria, infection risk, Salmonella.

Little has been done to investigate the occupational risk of working in bacterially contaminated air. The risk of infection is not restricted to the diseases normally regarded as airborne. Crozier and Woodward (6) demonstrated that it was possible to infect primates with Salmonella typhi through inhalation of a dose 1,000 times less than would be needed for an oral dose.

Studies have been carried out among sewage workers exposed to aerosols emitted from activated sludge tanks and trickling filters and among workers exposed to aerosols emitted during land application with treated sewage $(1,4)$. These outdoor studies have shown that in practice the health hazard associated with biological aerosols is low, even though the data published so far do not establish the magnitude of this risk. Consequently, an extensive prospective study was initiated among sewage workers (5).

The risk of infection from airborne microorganisms may be greater indoors

1 Institute of Hygiene, University of Aarhus, Denmark.

Reprint requests to: Dr. K. Grunnet, Institute of Hygiene, University of Aarhus, DK-8000 Aarhus $\mathrm{C}$, Denmark. due to less dilution (10). Apart from hospitals, the degree of bacterial air contamination has been registered only in a few workplaces and industries.

Heavy bacterial contamination of air may occur in industries such as paper pulp industries; the production of vegetable oils; meat-, bone-, and fishmeal factories; and other industries processing contaminated material of biological origin (2).

Since such contamination might represent a health hazard, we decided to investigate the bacterial air contamination in an industry processing imported vegetable material in order to evaluate the risk of infection in relation to exposure.

\section{MATERIAL AND METHOD}

Dust was collected in two areas with a varying degree of dust contamination. The concentration of dust in the air was calculated after collection on a Sartorius membrane filter $(0.8 \mu \mathrm{m} 160 \mathrm{~mm})$ with a Sartorius Gravicon apparatus, which filtered about $30 \mathrm{~m}^{3}$ of air per hour. 
Prior to the first weighing (four decimals) the membrane filters were dried at $150^{\circ} \mathrm{C}$ for $3 \mathrm{~h}$ and cooled in an exciccator containing silica gel; after sampling the filters were again dried and weighed.

The number and size of the particles were measured with a Climet particle counter (CI-252, Climet Instrument Co., Sunnyvale, Calif.), and the amount of respirable dust was calculated.

Dust for the bacteriological examination was collected under aseptic conditions into sterile bottles from shelves at heights of $1.5-1.8 \mathrm{~m}$ above the floor on $1 \mathrm{~d}$ in two areas. The shelves had been cleaned the day before collection.

Only this mixed sample was thoroughly investigated by the methods described in this report. However Salmonella concentrations in the same size range have been demonstrated on other occasions.

The dust was suspended in dilution water from which decimal dilutions were made. After filtration of $50 \mathrm{ml}$ of either the $1: 10^{6}$ dilution or the $1: 10^{7}$ dilution, the number of colonies was counted on a membrane filter on the following media: teepol agar, plate count agar, King's agar B (11), Slanetz agar, mannitol salt agar (12), and on Brilliant green agar (8).

All the colonies were isolated from one plate of the following media: nutrient agar, mannitol salt agar, brilliant green agar and teepol agar. After pure cultures had been obtained, all isolates were subjected to the following tests [a modified version of the method of Bonde (3)].

Stage I: gram staining and motility, O/Ftest of Hugh-Leifson, nitrate reduction test, Kovac's oxidase test.

Stage II (depending on the results of stage I): Leifson's flagella stain, indole, methyl-red, Voges-Proskauer, Simmon's citrate, glucose and lactose fermentation media, litmus milk, gelatin, coagulase, DNA-ase, hemolysis, and King's agar A and $B$ for fluorescein and pyocyanine formation, respectively.

Some strains were also subjected to special tests, such as elevated temperature and tests for urease.

These procedures result in identification at the genus level, in some cases also at the species level.
Moreover, the most probable number (MPN) of Escherichia coli (E. coli) (11) and Salmonella species (7) was measured.

At the time of the investigation 3 of the 20 workers had diarrhea. Six fecal samples were collected and examined for pathogenic intestinal bacteria by the Danish State Serum Institute (3 samples) and by our laboratory (3 samples).

\section{RESULTS}

\section{Dust examination}

The concentration of dust during the work hours varied from 1.5 to $10 \mathrm{mg} / \mathrm{m}^{3}$ in area I and up to $145 \mathrm{mg} / \mathrm{m}^{3}$ in area II.

About $5 \%$ of the dust below $1 \mu \mathrm{m}$, i.e., $80 \%$, was respirable $(1-5 \mu \mathrm{m})$.

General bacteriological examination gave a total count of 2.4 million per gram of dust, a figure which corresponds to 3,600-24,000 microorganisms per cubic meter for area I and up to 350,000 for area II.

The predominant organism was Bacillus species $(40-50 \%)$. An examination of selective media disclosed the following genera and species: Micrococcus species, Algaligines species, Coryne-bacteriaceae species, Erwinia species, Aeromonas species, Klebsiella aerogenes, Pseudomonas aeruginosa and other fluorescent pseudomonas. Frequently, yeast and fungi were also isolated.

A special examination for fecal contaminants showed a content of 1,700 coliform bacteria, $140 \mathrm{E}$. coli, 500,000 fecal streptococci, and 790 Salmonella spp. per gram of dust. The sero-fermentative typing of the Salmonella spp. demonstrated the presence of the following types: S.urbana, S.othmarshen, S.johannesburg, S.montevideo, S.tennessee, S.bloemfontein, S.mbandaka, S.oranienburg, and S.schwarzengrund.

\section{Examination of feces}

The examination of the feces failed to reveal any pathogenic bacteria. 


\section{DISCUSSION AND CONCLUSION}

On the basis of our findings of bacterial concentrations and the respiration volume during light work $\left[13 \mathrm{~m}^{3} / 8 \mathrm{~h}\right.$ (9)], the daily dose of pathogenic and potentially pathogenic organisms can be estimated approximately as: E.coli 20/day, Salmonella 100/day, Ps.aeruginosa 200/day in area I and up to E.coli 260/day, Salmonella $1,500 /$ day, and Ps.aeruginosa $3,000 /$ day in area II.

Compared to the normally accepted infective doses of about a million or more, these figures are low (7).

That no pathogens were demonstrated in the feces from the workers with diarrhea could be due to the fact that the workers were recovering at the time of the sampling. However, since no new cases have been reported during the following 14 months, a connection between the inhalation of pathogenic organisms and the diarrheas seems unlikely, and the reported inhalation doses of, e.g., 1001,500 Salmonella per day probably do not represent a health hazard to workers. However, the collection of dust by filtration (for weight) may give results that differ from those obtained by sedimentation (for bacteriological examinations). A particle must have an aerodynamic diameter of a minimum of $1 \mu \mathrm{m}$ to contain bacteria. The present investigation showed only $5 \%$ of the airborne particles to be below that size; consequently no great difference in bacterial concentration can be expected between dust collected after sedimentation or by filtration.

\section{ACKNOWLEDGMENT}

Thanks are due to Brest Nielsen of the
State Serum Laboratory, Copenhagen, for typing the Salmonella strains.

\section{REFERENCES}

1. ANDERS, W. Die Berliner Kanalbetriebsarbeiter. Z. Hyg. 139 (1954) 341-371.

2. ANDERSSON, R., BERGSTRÖM, B. and BUCHT, B. Outdoor sampling of airborne bacteria: Results and experiences. In: J. F. P. HERS and K. S. WINKLER (eds.), Airborne transmission and airborne infection. Oosthoek Publishing Co., Utrecht 1973, pp. $58-62$.

3. BONDE, G. J. Bacterial flora of synthetic carpets in hospitals (series no. 2). ISS Research Council, Copenhagen 1973, pp. 1-29.

4. BROWNING, G. E. and GANNON, J. J. Operator protection in wastewater treatment plants. J. water pollut. control fed. 35 (1963) 186-190.

5. CLARK, C. S., CLEARY, E. J., SCHIFF, G. M., LINNEMANN, C. C. JR., PHAIR, J. P. and BRIGGS, T. M. Disease risks of occupationel exposure to sewage. $J$. environ. eng. div. am. soc. civ. eng. 102 (1976) $375-388$.

6. CROZIER, D. and WOODWARD, T. E. Armed forces epidemiological board: Activities of the Commission on Epidemiological Survey, 1961. Mil. med. 127 (1962) 701705.

7. GRUNNET, K. Salmonella in sewage and receiving waters: Assessment of health hazards due to microbially polluted waters. FADL's forlag, Copenhagen 1975, pp. 4-9, $35-50$.

8. JEPSEN, A. Diagnostisk Bakteriologi og Levnedsmiddelbakteriologi. C. F. Mortensen, København 1960, pp. 187, 200.

9. TAYLOR, C. Studies in exercise physiology. Am. j. physiol. 27 (1941) 27-42.

10. WILLIAMS, R. E. O. Spread of airborne bacteria pathogenic for man. In: $P$. $H$. GREGORY and J. L. MONTEITH (eds.), Air-borne microbes, Cambridge 1967, pp. $268-285$.

11. - Forenklet bakteriologisk drikkevandsundersøgelse [Simplified procedure for bacteriological examination of drinking-water] (Danish standard no. 265.2). 1974, pp. 1-8.

12. - Oxoid manual (3rd ed). Berkshire Printing Co. Ltd., Reading 1972, pp. 179-180, $359-360$. 